\title{
Efektifitas Latihan Integrasi Visual Motorik terhadap Kemampuan Kesiapan Menulis Anak Attention Deficit Hyperactivity Disorder (ADHD)
}

\author{
Prasaja $^{1^{*}}$, Linda Harumi ${ }^{2}$ \\ ${ }^{1,2}$ Poltekkes Kemenkes Surakarta Jurusan Okupasi Terapi \\ *Email : prasajaahmad@gmail.com
}

\begin{abstract}
Background: Attention Deficit-Hyperactivity Disorder (ADHD) is a behavioral disorder characterized by inattention, hyperactivity, impulsivity that affected to the children's occupational performance in their activities. Individuals suffering from this disorder have a delayed development of visual-motor integration, difficulty participating in learning activities including writing readiness and poor academic progress. This research aims to (1) determine the effect of visual-motor integration activity interventions on writing readiness in ADHD children (2) find out the demographics of ADHD children based on age, gender and education. Methods: The design of this study was conducted a one group pre-experimental study using a pretest -posttest design. Samples were taken by purposive sampling technique. There were 35 samples consisting of 15 women and 20 men. The research instrument was the Beery DTVMI. Data analysis with paired parametric comparison test (paired sample t-test). Results: This study are (1) visualmotor integration activity interventions have a positive and significant effect on the writing readiness in ADHD children $(p=0,001)$. (2) ADHD children in YPAC Surakarta Occupational Therapy Clinic is dominated at the age of 5-6 years (54.3\%). (3) Most of the ADHD children in the YPAC Surakarta Occupational Therapy Clinic were male (57.1\%). (4) The education level of ADHD children in Surakarta YPAC Therapy Occupational Clinic was at the kindergarten level (51.4\%). Conclusion: This study is visual motor integration activity interventions be able to improve writing readiness in ADHD children.
\end{abstract}

Keywords: learning activities, the beery DTVMI, visual-motor integration activities

\section{PENDAHULUAN}

Salah satu gangguan perilaku pada anak-anak yang sering terjadi adalah Attention Deficit Hyperactive Disorder $(A D H D)$. Ini merupakan suatu kelainan neurobiologis yang dicirikan oleh adanya gangguan kemampuan memusatkan perhatian (inattention), mudah beralih perhatian (impulsivity), dan perilaku hiperaktif (hyperactivity) (Felt et al., 2014). Implikasi gangguan ini menjadikan anak - anak ADHD mengalami ketidakmampuan untuk duduk tenang lebih dari beberapa menit, suka mengganggu, sering tantrum, keras kepala dan seolah-olah mengabaikan hukuman.

Para peneliti sebelumnya melaporkan bahwa anak-anak ADHD mengalami kesulitan mengikuti pembelajaran di sekolah. Mereka harus mengulang kelas satu kali (50-85\%), mengulang kelas dua sampai tiga kali (30 $\%)$, dan mengikuti kelas khusus (10\%), salah satu sebabnya karena mereka kurang mampu dalam hal kesiapan menulis. Menulis adalah satu dari keterampilanketerampilan penting yang harus diperoleh anak saat sekolah dasar (Lust \& Donica, 2011). Menulis membuat anak mampu mengungkapkan ide-ide, mempertahankannya dan mengadakan komunikasi interpersonal (Feder \& Majnemer, 2007). Menulis akan mempengaruhi keberhasilan atau kegagalan memenuhi persyaratan persyaratan dalam mencapai kemampuan di sekolah (Graham \& Harris, 2005). Komponen-komponen motorik dan perceptual yang berhubungan dengan menulis diantaranya persepsi visual, kemampuan kontrol motorik halus, 
integrasi visual motorik, kinesthesia, modalitas sensori, dan sustained attention (Cornhill, 1996).

Penelitian sebelumnya oleh LeGear et al (2012) lebih menekankan kepada hubungan kecakapan keterampilan motorik dan persepsi visual secara terpisah. Belum ada penelitian di Indonesia yang meneliti bagaimana integrasi visual motorik berperanan dalam kemampuan kesiapan menulis pada anakanak ADHD. Ada banyak faktor yang berpengaruh seperti persepsi visual, motor planning, motor memory, sequencing (Pfeiffer et al., 2015). Menurut (Oraky et al., 2017), integrasi visual-motor adalah prediktor yang sangat penting dalam performa kesiapan menulis.

Tujuan penelitian ini untuk mengetahui efektifitas intervensi aktivitas integrasi visual - motor terhadap kesiapan menulis anak-anak ADHD.

\section{METODE PENELITIAN}

One group pre-experimental study tipe pretest-posttest design digunakan pada penelitian ini. Peneliti memberi intervensi latihan integrasi visual motorik dengan aktivitas in hand manipulation (meliputi meremas bola dengan gradasi ukuran, tekstur, kepadatan bola dan mencetak playdough dengan cetakan huruf) dan aktivitas motor planning (meliputi bermain puzzle huruf, coloring, melatih anak menggunakan papan belat huruf) serta aktivitas bilateral integration (meliputi menggulung, memotong playdough menggunakan pisau plastik dan menyobek kertas). Latiihan dilakukan sesuai dengan modul yang disusun peneliti, menggunakan program training dengan 6 kali sesi terapi berdurasi 50 menit. Program training dilakukan oleh okupasi terapis di YPAC Surakarta.

Sampel diambil dari anak-anak ADHD di Klinik Okupasi Terapi YPAC Surakarta melalui teknik purpossive sampling, dengan kriteria inklusi sebagai berikut : (1) Anak ADHD usia 2 - 7 tahun yang mempunyai masalah kesiapan menulis sesuai dengan instrumen pemeriksaan (2) Bersedia sebagai subyek penelitian dari awal sampai akhir. Sedangkan kriteria eksklusinya adalah : (1) Anak dengan gangguan indera penglihatan (2) Anak ADHD yang sudah mendapatkan terapi latihan visual motorik sebelumnya. Jumlah sampel pada penelitian ini sebanyak 35 anak.

Penelitian ini menggunakan Instrumen Beery - Buktenica Developmental Test Visual Motor Integration (Beery ${ }^{\mathrm{TM}} \mathrm{VMI}$ ) edisi ke enam. Instrumen ini merupakan suatu penilaian koordinasi mata-tangan melalui kegiatan menyalin bentuk-bentuk geometris bagi anak-anak maupun orang dewasa. Beery VMI bertujuan untuk membantu mengidentifikasi kesulitan yang signifikan dalam visual motor integration, mendapatkan layanan yang dibutuhkan bagi pasien, menilai efektivitas pendidikan dan program intervensi lainnya dan sebagai alat penelitian (Pfeiffer et al., 2015). Cara penilaian dengan cara anak diminta membentuk atau membuat garis vertikal (I), garis horizontal (-), lingkaran $(\mathrm{O})$, garis tambah (+), garis miring kanan dan kiri $(/, I)$, bentuk persegi ( $\square$ ), bentuk segitiga $(\boldsymbol{\Delta})$, garis silang $(\mathrm{X})$, diberi skor 1 bila memenuhi kriteria, dan 0 bila tidak memenuhi kriteria. 
HASIL PENELITIAN

Tabel 1. Deskripsi Demografi Subyek Penelitian

\begin{tabular}{lccc}
\hline Subyek penelitian & Rentang Usia & $\begin{array}{c}\text { Frekuensi } \\
(\mathbf{n = 3 5})\end{array}$ & $\begin{array}{c}\text { Prosentase } \\
(\mathbf{n = 1 0 0 \% )}\end{array}$ \\
\hline \multirow{2}{*}{ Usia } & $\leq 4$ th & 6 & 17.1 \\
& $5-6$ th & 19 & 54.3 \\
\multirow{2}{*}{ Jenis Kelamin } & $>6$ th & 10 & 28.6 \\
& Perempuan & 15 & 42.9 \\
\multirow{2}{*}{ Pendidikan } & Laki-laki & 20 & 57.1 \\
& PAUD & 6 & 17.1 \\
& TK & 18 & 51.4 \\
\hline
\end{tabular}

Sumber: Diolah dari data primer

Tabel 1. menunjukkan gambaran demografi subyek penelitian, berdasarkan kelompok usia, responden terbanyak pada rentang usia $5-6$ tahun berjumlah 19 subyek $\quad(54,3 \%)$, jenis kelamin didominasi oleh laki - laki berjumlah 20 subyek $(57,1 \%)$, dan pendidikan terbanyak pada tingkat TK berjumlah 16 subyek $(51,4 \%)$.

Uji prasyarat hipotesis dilakukan untuk mengetahui apakah data berdistribusi normal. Hasil uji normalitas (Shapiro-Wilk test) sebelum intervensi
0,450 dan sesudah intervensi 0,441 . Hal ini berarti bahwa data skor hasil tes Beery DTVMI sebelum dan sesudah intervensi berdistribusi normal.

Untuk mengetahui apakah ada perbedaan kemampuan kesiapan menulis pada subyek penelitian sebelum dilakukan intervensi latihan visual motor integrasi dengan setelah dilakukan intervensi dilakukan uji beda rerata skor hasil tes Beery DTVMI dengan menggunakan paired parametric comparison test (paired sample t-test).

Tabel 2. Uji Hipotesis Perbedaan Rerata Skor Beery DTVMI

\begin{tabular}{lccccc}
\hline \multirow{2}{*}{ Kelompok } & \multirow{2}{*}{ R } & \multirow{2}{*}{ Rerata } & SB & \multicolumn{2}{c}{ paired t-test } \\
\cline { 5 - 6 } & & & & $\mathbf{t}$ & $\mathbf{p}$ \\
\hline Sebelum & 35 & 12,69 & 2,587 & $-9,976$ & 0,001 \\
Sesudah & 35 & 14,40 & 2,354 & & \\
\hline
\end{tabular}

Sumber : Olah data SPSS versi 17 (2017)

Tabel 2. menyajikan hasil uji paired parametric comparison test (paired sample t-test) perbedaan rerata skor test Beery DTVMI pada kelompok data sebelum intervensi dan sesudah intervensi aktivitas integrasi visual motorik dimana mendapatkan hasil nilai $\mathrm{p}=0,001(<0,05)$. Nilai tersebut menunjukkan bahwa terdapat beda rerata skor test Beery DTVMI secara positif dan bermakna antara sebelum dan sesudah intervensi aktivitas integrasi visual motor. Dengan demikian intervensi aktivitas integrasi visual motor pada anak-anak ADHD efektif untuk meningkatkan kemampuan kesiapan menulis. 


\section{PEMBAHASAN}

Tempat pelaksanaan penelitian di Klinik Okupasi Terapi YPAC Surakarta Jl. Slamet Riyadi No. 364 Surakarta 57141, Jawa Tengah, merupakan klinik dan sekolah anak-anak berkebutuhan khusus dengan berbagai kondisi. Sebaran usia subyek penelitian didominasi pada rentang rentang usia $5-6$ tahun, sesuai dengan statistik pendidikan di Indonesia bahwa pada tahun 2015 populasi penduduk usia sekolah di Indonesia jumlah terbanyak pada rentang usia 4,01 6,09 tahun (33.517.600 jiwa), paling sedikit pada rentang usia 16 - 18 tahun (13.281.300 jiwa). Salah satu faktor yang berpengaruh terhadap kemampuan kesiapan menulis adalah kematangan usia anak, semakin matang usia anak semakin besar anak untuk bisa berpartisipasi dalam kegiatan pembelajaran. Usia anak yang relatif lebih muda, dia akan mempunyai pengalaman belajar kurang sehingga anak yang lebih tua usianya mempunyai kemampuan kesiapan menulis lebih baik (Patel et al., 2017).

Distribusi jenis kelamin subyek penelitian lebih banyak laki - laki. Perkembangan kesiapan menulis anak juga dipengaruhi oleh jenis kelamin. Keterampilan motorik anak dipengaruhi oleh beberapa faktor internal, salah satunya jenis kelamin. Pada anak perempuan mempunyai kemampuan koordinasi motorik dan kontrol gerakan tubuh lebih baik daripada anak laki-laki. Pada anak perempuan sifat lebih tekun dalam melakukan suatu aktivitas variabel pembeda dalam hal ini, namun seiring dengan bertambahnya usia anak, perbedaan ini perlahan-lahan berkurang (Studi et al., 2017)

Hasil uji paired parametric comparison test (paired sample t-test) skor Beery DTVMI antara sebelum dan sesudah intervensi mendapatkan nilai $\mathrm{p}=$ 0,001. Nilai tersebut berarti bahwa terdapat beda rerata skor Beery DTVMI secara statistik bermakna saat sebelum dan sesudah diberi intervensi aktivitas integrasi visual - motor. Apabila dikaitkan dengan hipotesis penelitian berarti intervensi aktivitas integrasi visual motor efektif dalam meningkatkan kemampuan kesiapan menulis pada anakanak Attention Deficit Hyperactive Disorder (ADHD).

Intervensi aktivitas integrasi visual motor berperan untuk memperbaiki kemampuan kesiapan menulis. Sebagaimana ditulis oleh (Qian et al., 2013), bahwa pada otak mammalia dikeluarkan dopamine yang merupakan salah satu neuromodulator paling kuat untuk mempengaruhi fungsi sirkuit dan plastisitas otak. Ia berperan penting dalam mengontrol pergerakan tubuh, membangkitkan motivasi, meningkatkan gairah, mempengaruhi kognisi dan reward. Hal inilah yang dapat meningkatkan minat dan konsentrasi dalam beraktivitas. Penelitian lainnya tentang teori plastisitas otak menjelaskan bahwa sirkuit-sirkuit neuronal bisa dimodifikasi melalui pemberian pengalaman baru yang dilatihkan secara berulang-ulang, pemberian terapi farmakologis, serta pembelajaran yang terprogram. Perbaikan lesi di otak dapat terjadi dengan program tersebut (Kolb et al., 2017). Plastisitas otak khususnya pada bagian kortikal dapat terbentuk sebagai respon terstruktur terhadap berbagai intervensi eksperimental dari latihan yang terprogram. Keterlibatan dopamine sebagai modulator, merupakan kunci perbaikan plastisitas otak dalam sirkuit corticostriatal yang dapat dihasilkan saat 
belajar pengalaman baru yang terprogram melalui intervensi visual motor training (Pawlak \& Kerr, 2008).

Peneliti lain menjelaskan bahwa kemampuan integrasi visual - motor dibutuhkan dalam aktivitas sehari-hari seperti berjalan, mengetik, menulis, mengambil gelas, dan sebagainya. Kualitas hidup seseorang dipengaruhi oleh kematangan kemampuan integrasi visual motor (Wuang et al., 2012).

Sebagian besar anak-anak $A D H D$ mengalami gangguan dalan occupational performance. Mereka memiliki energi fisik yang lebih besar, kesulitan dalam tugas motorik kasar seperti melempar dan menangkap bola, kesulitan mengikuti pembelajaran, seringkali anak ADHD mendapatkan nilai buruk di sekolah (Campbell \& Burgess, 2012). Sebagai konsekuensinya, anak-anak ADHD kurang ikut berpartisipasi dalam kegiatan sekolah dan kurang motivasi untuk berinteraksi sosial, dan memiliki kepercayaan diri rendah serta menarik diri dari aktivitas sosial (Costini et al., 2017).

\section{KESIMPULAN DAN SARAN}

Kemampuan kesiapan menulis pada anak-anak Attention Defisit Hyperactivity Disorder (ADHD) dapat ditingkatkan melalui intervensi aktivitas integrasi visual motor. Kematangan kemampuan integrasi visual-motor diperlukan anak untuk memperkuat otot kaki dan tangan, melatih konsentrasi, meningkatkan sosialitas, meningkatkan sensitivitas dan partisipasi anak-anak $A D H D$ dalam aktivitas pembelajaran. Usia terbanyak subyek penelitian pada rentang usia $5-6$ tahun, jenis kelamin didominasi oleh laki - laki.

\section{DAFTAR RUJUKAN}

Campbell, C., \& Burgess, R. (2012). The role of communities in advancing the goals of the Movement for Global Mental Health. Transcultural Psychiatry, 49(4), 379-395. https://doi.org/10.1177/1363461512 454643

Cornhill, H. (1996). Factors that relate to good and poor handwriting. American Journal of Occupational Therapy, 50(9), 737-739. https://doi.org/10.5014/ajot.50.9.732

Costini, O., Roy, A., Remigereau, C., Faure, S., Fossoud, C., \& Le Gall, D. (2017). Nature and specificity of gestural disorder in children with developmental coordination disorder: A multiple case study. Frontiers in Psychology, 8(JUL), 113.https://doi.org/10.3389/fpsyg.201 7.00995

Feder, K. P., \& Majnemer, A. (2007). Handwriting development, competency, and intervention. Developmental Medicine and Child Neurology, 49(4), 312-317. https://doi.org/10.1111/j.14698749.2007.00312.x

Felt, B. T., Biermann, B., Christner, J. G., Kochhar, P., \& Van Harrison, R. (2014). Diagnosis and management of ADHD in children. American Family Physician, 90(7), 456-464.

Graham, S., \& Harris, K. R. (2005). Improving the writing performance of young struggling writers: Theoretical and programmatic research from the center on 
Accelerating Student Learning. Journal of Special Education, 39(1), 19-33.

https://doi.org/10.1177/0022466905 0390010301

Kolb, B., Harker, A., \& Gibb, R. (2017). Principles of plasticity in the developing brain. Developmental Medicine and Child Neurology, 59(12), 1218-1223. https://doi.org/10.1111/dmcn.13546

LeGear, M., Greyling, L., Sloan, E., Bell, R. I., Williams, B. L., Naylor, P. J., \& Temple, V. A. (2012). A window of opportunity? Motor skills and perceptions of competence of children in Kindergarten. International Journal of Behavioral Nutrition and Physical Activity, 9(1), 29. https://doi.org/10.1186/1479-58689-29

Lust, C. A., \& Donica, D. K. (2011). Effectiveness of a handwriting readiness program in head start: A two-group controlled trial. American Journal of Occupational Therapy, 65(5), $560-568$ https://doi.org/10.5014/ajot.2011.00 0612

Oraky, S. M., Tawfik, S., Salama, M., \& Mohamed, E. S. (2017). Comparing outcome of formal and informal remediation programs in children with central auditory processing disorder. The Egyptian Journal of Otolaryngology, 33(4), 663-669. https://doi.org/10.4103/ejo.ejo
Patel, D. R., Soares, N., \& Wells, K. (2017). Neurodevelopmental readiness of children for participation in sports. Translational Pediatrics, 6(3), 167-173. https://doi.org/10.21037/tp.2017.05. 03

Pawlak, V., \& Kerr, J. N. D. (2008). Dopamine receptor activation is required for corticostriatal spiketiming-dependent plasticity. Journal of Neuroscience, 28(10), 24352446. https://doi.org/10.1523/JNEUROSC I.4402-07.2008

Pfeiffer, B., Moskowitz, B., Paoletti, A., Brusilovskiy, E., Zylstra, S. E., \& Murray, T. (2015). Developmental Test of Visual-Motor Integration (VMI): An effective outcome measure for handwriting interventions for kindergarten, firstgrade, and second-grade students? American Journal of Occupational Therapy, 69(4), 1-7. https://doi.org/10.5014/ajot.2015.01 5826

Qian, Y., Chen, M., Forssberg, H., \& Diaz Heijtz, R. (2013). Genetic variation in dopamine-related gene expression influences motor skill learning in mice. Genes, Brain and Behavior, 12(6), 604-614.

Studi, P., Dan, P., Indonesia, S., Keguruan, F., Ilmu, D. A. N., \& Purworejo, U. M. (2017). Dengan Metode Pemodelan Pada Siswa Kelas Viii Smp Negeri 4 Purworejo Tahun Pelajaran 2016 / 2017 Skripsi. 
Wuang, Y. P., Su, J. H., \& Su, C. Y. (2012). Reliability and responsiveness of the Movement Assessment Battery for ChildrenSecond Edition Test in children with developmental coordination disorder. Developmental Medicine and Child Neurology, 54(2), 160 165. https://doi.org/10.1111/j.14698749.2011.04177.x 